\title{
Effect of different modules on yield and yield attributes of cluster bean [Cyamopsis tetragonoloba (L.) Taub.] grown on light textured soil of Kachchh region
}

\section{A.H. SIPAI, KULDEEP SEVAK, K.U. KHORAJIYA, KOTRAMMA ADDANGADI AND A. N. CHAUDHARY}

Received : 21.02.2017; Revised : 25.04.2017; Accepted : 07.05.2017

\section{MEMBERS OF RESEARCH FORUM:}

Corresponding author : A.H. SIPAI, Regional Research Station (S.D.A.U.) Bhachau, KACHCHH (GUJARAT) INDIA Email: Sipaisoil@gmail.com

Co-authors : KULDEEP SEVAK, K.U. KHORAJIYA, KOTRAMMA ADDANGADI AND A. N. CHAUDHARY, Regional Research Station (S.D.A.U.) Bhachau, KACHCHH (GUJARAT) INDIA

\section{Summary}

Cluster bean [Cyamopsis tetragonoloba (L.) Taub.] which is locally known as "guara" belongs to the family Fabaceae. It is hardy crop and its cultivation is suitable for rainfed, low fertility soil conditions. A field experiment consisting of five different modules was conducted during Kharif season from 2009-10 to 2014-15 with five quadrates in each module $(2 \mathrm{~m} \times 2 \mathrm{~m})$ under Randomized Block Design at Regional Research Station, SDAU, Bhachau, Kachchh to study the effect of different modules on yield and yield attributes of cluster bean grown on light textured soil of Kachchh. Among the five different modules, three were organic modules, one was chemical module and control. The results of the experiments differed significantly. The significant improvement in yield attributes and yield were recorded with the chemical module $\mathrm{T}_{4}$. Organic modules $\mathrm{T}_{2}$ recorded the highest growth improvement and yield as compared to control.

Key words : Yield, Yield attributes, FYM, Vermi compost, VAM

How to cite this article : Sipai, A.H., Sevak, Kuldeep, Khorajiya, K.U., Addangadi, Kotramma and Chaudhary, A.N. (2017). Effect of different modules on yield and yield attributes of cluster bean [Cyamopsis tetragonoloba (L.) Taub.] grown on light textured soil of Kachchh region. Asian J. Soil Sci., 12 (1) : 116-120 : DOI : 10.15740/HAS/AJSS/12.1/116-120. 